\title{
Photo Stimulation of Seminal Doses with Red LED Light from Duroc Boars and Resultant Fertility in Iberian Sows
}

\author{
Sara Crespo ${ }^{1,2, *}$, Mateo Martínez ${ }^{2}$ and Joaquín Gadea ${ }^{1, *(D)}$ \\ 1 Department of Physiology, International Excellence Campus for Higher Education and Research "Campus \\ Mare Nostrum" and Institute for Biomedical Research of Murcia (IMIB-Arrixaca), University of Murcia, \\ 30100 Murcia, Spain \\ 2 Technical Department, CEFU, SA, Alhama de Murcia, 30840 Murcia, Spain; mateo.martinez@cefusa.com \\ * Correspondence: sara.crespo@cefusa.com (S.C.); jgadea@um.es (J.G.); Tel.: +34-868-884655 (J.G.)
}

\section{check for}

updates

Citation: Crespo, S.; Martínez, M.; Gadea, J. Photo Stimulation of Seminal Doses with Red LED Light from Duroc Boars and Resultant Fertility in Iberian Sows. Animals 2021, 11, 1656. https://doi.org/ 10.3390/ani11061656

Received: 3 May 2021

Accepted: 27 May 2021

Published: 2 June 2021

Publisher's Note: MDPI stays neutral with regard to jurisdictional claims in published maps and institutional affiliations.

Copyright: (c) 2021 by the authors. Licensee MDPI, Basel, Switzerland. This article is an open access article distributed under the terms and conditions of the Creative Commons Attribution (CC BY) license (https:// creativecommons.org/licenses/by/ $4.0 /)$.
Simple Summary: The main objective of breeding Iberian pigs is the production of high-quality dry cured meat products. As this breed shows a reduced litter size in comparison to the commercial breeds, some previous studies have reported the use of photostimulation of seminal doses as a method for improving the farrowing rate and litter size. The aim of this study was to explore whether the application of a photostimulation procedure to Duroc seminal doses has any beneficial effect on fertility and litter size. Semen samples were obtained from 38 fertile Duroc boars and the fertility study was conducted on two commercial farms using multiparous Iberian sows (farm A, $\mathrm{n}=824$; farm $B, n=2131$ ), that were randomly assigned to LED (L) or control (C) groups. Post-cervical insemination took place 0 and $24 \mathrm{~h}$ after the diagnosis of estrus, with seminal doses from the same ejaculate and same treatment. The photostimulation of the seminal doses had no effect on the reproductive performance (farrowing rate: $91.72 \% \mathrm{C}$ vs. $90.09 \% \mathrm{~L}$, litter size: $8.71 \pm 0.06$ piglets $\mathrm{C}$ vs. $8.70 \pm 0.05 \mathrm{~L}, p>0.05)$

Abstract: In pigs, it has been reported that increased farrowing rates and litter size have been induced by photostimulating the seminal doses for artificial insemination with red LED light. As the reproductive characteristics, production system, and outcome parameters of Iberian breed pigs are different from other commercial breeds, the aim of this study was to evaluate the possible effect of illuminating seminal doses from Duroc boars with red LED light and the fertility outcomes of Iberian females. Semen samples were obtained from 38 fertile Duroc boars. Photostimulation of the artificial insemination (AI) seminal doses was carried out by illuminating the samples with a red LED for $10 \mathrm{~min}$, followed by $10 \mathrm{~min}$ of darkness, and finally 10 additional minutes of red light. The fertility study was conducted on two commercial farms using multiparous Iberian sows (farm A, n = 824; farm $B, n=2131$ ), that were randomly assigned to LED (L) or control (C) groups. No differences were found between $L$ and $C$ groups in both farms $(p>0.05)$ for parity, pregnancy rate, duration of pregnancy, farrowing rate, and litter size (total, alive, and stillborn piglets). Farrowing rates in farm A were 88.8\% $(n=383)$ for control and 89.6\% $(n=441, p=0.67)$ for the LED group. In farm $\mathrm{B}$, farrowing rates were C:90.5\% $(\mathrm{n}=1030)$ and $\mathrm{L}: 90.1 \%(\mathrm{n}=1101, p=0.48)$. In farm A, total born piglets were $8.69 \pm 0.11$ for $\mathrm{C}$ and $8.71 \pm 0.11$ for $\mathrm{L}(p=0.87)$. In farm $\mathrm{B}$, the results were $8.72 \pm 0.7$ for $\mathrm{C}$ and $8.70 \pm 0.06(p=0.82)$ for $\mathrm{L}$. Under the production conditions for the Iberian breed, the photostimulation with red LED light using Duroc pig seminal doses was not effective in improving the fertility of Iberian sows.

Keywords: porcine AI; spermatozoa; reproductive outcomes

\section{Introduction}

Previous studies have pointed out the sensitivity of sperm cells to light exposure. Differences between species, type of light, intensity and duration of the illumination 
used in these studies have produced controversial outcomes [1-3]. In pigs, a red LEDbased photostimulation procedure (10 min illumination, 10 darkness and 10 illumination) increased the achievement of in vitro capacitation and subsequent progesterone-induced acrosome reaction [4]. In relation to in vivo fertility outcomes in pigs, increased farrowing rates and litter sizes have been reported following photostimulation of the seminal doses for artificial insemination by red LED light $[4,5]$.

The previous studies were developed with commercial breeds in mind, mainly Large White and landrace breeds. However, the reproductive parameters and outcomes of the Iberian breed are different from the commercial breeds [6,7]. Normal practices and regulations related to Iberian pig products dictate that the sow is Iberian, whereas the boar could be Iberian, Duroc, or a hybrid between the two [8]. The Duroc crossing provides increased prolificacy and productive performance [9,10]. According to Casellas et al. [11], in 2019, the litter size in different varieties of Iberian breed ranged from 8.02 for the Entrepelado variety and 8.40 for the Rentito variety, and these values are different from the data reported for the hyper-prolific genetic lines that are currently being bred, with frequent litters of 18-20 piglets [12].

One of the main objectives in the production of the Iberian breed is the improvement in the reproductive outcomes, especially the litter size, while maintaining the special characteristics of the carcass, destined to be processed as high-quality dry cured meat products [13]. Therefore, the aim of this study was to evaluate the possible beneficial effect on reproductive parameters of illuminating seminal doses from Duroc boars with red LED light in their specific production system.

\section{Materials and Methods}

\subsection{Ethics}

The study was developed according to Spanish Policy for Animal Protection (RD 53/2013), which conforms to European Union Directive 2010/63/EU regarding the protection of animals used in scientific experiments.

\subsection{Semen Recovery and Seminal Doses Preparation}

Semen samples were obtained from 38 fertile, healthy, and sexually mature Duroc boars. The age of the boars was $20.10 \pm 1.78$ months old, ranging from 10 to 45 months. All boars were housed in two artificial insemination (AI) centers located in Murcia (Spain). The boars were subjected to the same management conditions, specifically, they were housed in individual pens in buildings with a controlled light regime ( $16 \mathrm{~h}$ per day) and temperature $\left(15-25^{\circ} \mathrm{C}\right)$ and with free access to water. The boars were fed with commercial feedstuff according to the nutritional requirements for adult boars subjected to regular ejaculate collection (once or twice per week) [14].

Sperm-rich fractions were collected by an experienced operator using the gloved hand technique [15] and immediately transported to the laboratory. The sperm-rich fraction was diluted with a commercial extender (MR-A, KUBUS SA, Madrid, Spain), split into seminal doses of $80 \mathrm{~mL}$ and cooled to $16{ }^{\circ} \mathrm{C}$, with total motility and normal morphology higher than $70 \%$, and $3 \times 10^{9}$ spermatozoa per seminal dose, and stored at $16^{\circ} \mathrm{C}$ for up to $48 \mathrm{~h}$ before AI.

For motility evaluation, two subsamples were placed on warm glass slides $\left(38^{\circ} \mathrm{C}\right)$ and examined under a contrast phase microscope at $200 \times$ magnification. The percentage of motile sperm cells was estimated subjectively to the nearest $5 \%$ using an arbitrary scale of $0-100 \%$ [16].

Sperm samples were fixed and diluted $1: 10(v / v)$ in saline with $0.3 \%$ formaldehyde. A Bürker counting chamber was used to evaluate sperm concentration by contrast phase microscopy at $200 \times$ magnification, counting each sample in duplicate. To evaluate sperm morphology, a $10 \mu \mathrm{L}$ sample drop was placed on a slide, covered with a $24 \mathrm{~mm} \times 24 \mathrm{~mm}$ cover slip and morphology was evaluated by contrast phase microscopy at $1000 \times$ magnification (Leica DMR, Wetzlar, Germany). Two hundred spermatozoa per sample were 
counted and classified into sperm with normal morphology, sperm with proximal cytoplasmatic droplets, sperm with distal cytoplasmatic droplets, sperm with tail defects (folded and coiled tail), and sperm with other abnormal morphologies [16].

\subsection{Photostimulation of Seminal Doses}

Photo stimulation of the AI seminal doses was carried out using a commercial system (Maxipig, IUL SA, Barcelona, Spain) that illuminated the samples with red LED with a program of $10 \mathrm{~min}$ of light, followed by $10 \mathrm{~min}$ of darkness and finally another $10 \mathrm{~min}$ of light exposure [4]. The chamber maintained the temperature of the samples at $16{ }^{\circ} \mathrm{C}$ during the process.

\subsection{Fertility Trial}

The fertility study was conducted on two commercial farms in Murcia (Spain) using multiparous Iberian sows (parity range 2-11). After weaning, estrus was checked daily in the presence of a mature teaser boar. Occurrence of estrus was defined by the standing reflex in front of a boar (back pressure test) and reddening and swelling of the vulva. Post-cervical insemination took place $0 \mathrm{~h}$ after the diagnosis of estrus and was repeated $24 \mathrm{~h}$ later, using disposable post cervical AI catheters (Soft \& Quick, Tecnovet SL., Barcelona, Spain) [17]. First and second artificial inseminations were performed with seminal doses with $3 \times 10^{9}$ spermatozoa from the same ejaculate and the same treatment (LED or control). Inseminations were performed during the period 1 August 2018 to 31 December 2018.

Fertility was measured for every ejaculate as pregnancy rate (the percentage of sows with positive ultrasound diagnostic at day 30 after insemination to $\mathrm{AI}$ ) and farrowing rate (the percentage of sows farrowing to AI). For each farrowed sow, the number of dead piglets (NBD) and piglets born alive (NBA) was recorded, and the sum was defined as the total number of piglets born (TB).

In study A, insemination doses from boars recovered on Monday and Wednesday were assigned to LED groups, and seminal doses recovered on Tuesday and Thursday were assigned to the control group. All the boars included in this study had samples that were photostimulated and some that were control. In study B, insemination doses from the same ejaculate every day were split into two groups (LED and control).

\subsection{Statistical Analysis}

\subsubsection{Sample Size}

We planned a study of independent cases and controls. Prior data indicated that the probability of exposure among controls was 0.87 [5]. If the true probability of exposure among cases was 0.91 , we needed to study 960 cases and 960 controls to be able to reject the null hypothesis that the exposure rates for cases and controls are equal with a probability (power) of 0.8 . The type I error probability associated with the test of this null hypothesis was 0.05 . We used an uncorrected chi-squared statistic to evaluate this null hypothesis [18]. Finally, we studied 1413 controls and 1542 cases (LED), which was 50\% higher than the calculated sample size.

\subsubsection{Data Analysis}

The results are expressed as mean \pm SEM and were analyzed by two-way ANOVA, considering the specific photostimulation treatment as a main variable and the other variables being the farm, parity, or boar. Pregnancy and farrowing data were modeled according to the binomial model of parameters and were analyzed by two-way ANOVA. When ANOVA revealed a significant effect, values were compared by Tukey's test. Differences were considered statistically significant at $p<0.05$.

Linear regression was used to further investigate relationships between litter size and measured semen parameters (Pearson's correlation). Multiple regression was used to explore relationships between litter size and other factors. 


\section{Results}

A total of 152 ejaculates from 38 boars were used in this study, with a volume of $179.34 \pm 7.31$; sperm concentration $591.11 \pm 13.21 \times 10^{6} \mathrm{sperm} / \mathrm{mL} ; 106.01 \pm 3.74 \times 10^{9}$ sperm in the ejaculate; with $12.38 \pm 0.81 \%$ morpho-anomalies, distributed as $1.84 \pm 0.24 \%$ sperm with tail defects, $4.82 \pm 0.36 \%$ with cytoplasmic proximal droplets, and $5.72 \pm 0.55$ with distal ones.

The photostimulation of the seminal doses had no effect on the reproductive performance (pregnancy rate, farrowing rate, litter size) in both farms. No differences were found between LED (L) and control (C) groups in either farm $(p>0.05)$ for pregnancy rate, duration of pregnancy, farrowing rate, and litter size (total, alive, and stillborn piglets). Farrowing rates in farm A were $88.77 \%(\mathrm{n}=383)$ for control and $89.57 \%(\mathrm{n}=441, p=0.90)$ for the LED group. In farm B, the results were C: $90.53 \%(n=1035)$ and $L: 90.11 \%(n=1101$, $p=0.48$ ). In farm $A$, total born piglets were $8.69 \pm 0.11$ for $C$ and $8.71 \pm 0.11$ for $\mathrm{L}$. In farm $\mathrm{B}$, the results were $8.72 \pm 0.07$ for $\mathrm{C}$ and $8.70 \pm 0.06$ for $\mathrm{L}(p=0.98)$ (Table 1$)$.

Table 1. Fertility outcomes of sows inseminated with seminal doses after photostimulation by LED or not (control). Data expressed as mean $\pm \mathrm{SEM}$.

\begin{tabular}{|c|c|c|c|c|c|c|c|}
\hline Farm & Group & $\mathbf{N}$ & Pregnancy Rate & Farrowing Rate & NBA & NBD & TB \\
\hline $\mathrm{A}$ & Control & 383 & 92.43 & 88.77 & $8.35 \pm 0.11$ & $0.34 \pm 0.03$ & $8.69 \pm 0.11$ \\
\hline A & LED & 441 & 93.20 & 89.57 & $8.35 \pm 0.10$ & $0.37 \pm 0.03$ & $8.71 \pm 0.11$ \\
\hline B & Control & 1030 & 91.40 & 90.53 & $8.40 \pm 0.07$ & $0.32 \pm 0.02$ & $8.72 \pm 0.07$ \\
\hline B & LED & 1101 & 91.47 & 90.11 & $8.42 \pm 0.06$ & $0.28 \pm 0.02$ & $8.70 \pm 0.06$ \\
\hline Total & Control & 1413 & 91.72 & 90.09 & $8.8 \pm 0.06$ & $0.32 \pm 0.02$ & $8.71 \pm 0.06$ \\
\hline Total & LED & 1542 & 91.96 & 89.95 & $8.40 \pm 0.05$ & $0.30 \pm 0.02$ & $8.70 \pm 0.05$ \\
\hline \multicolumn{8}{|c|}{$p$ Value } \\
\hline \multicolumn{3}{|c|}{ Source of Variation } & Pregnancy Rate & Farrowing Rate & NBA & NBD & ТВ \\
\hline \multicolumn{3}{|c|}{ Treatment } & 0.08 & 0.25 & 0.62 & 0.45 & 0.80 \\
\hline \multicolumn{3}{|c|}{ Farm } & 0.11 & 0.50 & 0.46 & $<0.01$ & 0.04 \\
\hline \multicolumn{3}{|c|}{ Parity } & 0.43 & 0.05 & $<0.01$ & $<0.01$ & $<0.01$ \\
\hline \multicolumn{3}{|c|}{ Farm Treatment } & 0.10 & 0.14 & 0.66 & 0.42 & 0.48 \\
\hline \multicolumn{3}{|c|}{ Parity Treatment } & 0.10 & 0.53 & 0.97 & 0.79 & 0.93 \\
\hline \multicolumn{3}{|c|}{ Farm Parity } & 0.43 & 0.11 & 0.77 & 0.10 & 0.92 \\
\hline \multicolumn{3}{|c|}{ Treatment ${ }^{*}$ Farm * Parity } & 0.30 & 0.21 & 0.87 & 0.50 & 0.91 \\
\hline
\end{tabular}

NBA: number of piglets born alive. NBD: number of piglets born dead (NBD). TB: total number of piglets born.

Once we had not found any differences in the reproductive performance between LED and control groups, we studied other possible factors that could have affected the results, such as parity number, males, or sperm quality. No differences were found in fertility outcomes between LED and control groups for every group of parity. Parity influenced pregnancy and farrowing rate and litter size (TB and NBA) (Table 2).

The boar had a direct effect on farrowing and litter size, but not on pregnancy rate. No differences were found for the interaction between LED treatment and boar, which means that all boars followed the same pattern after photostimulation (Table 3). The analysis of the correlation between seminal parameters $(n=152)$ and fertility outcomes pointed out only a tendency $(p=0.09)$ for an inverse relationship $(\mathrm{r}=-0.14)$ between percentage of proximal cytoplasmic droplets and pregnancy rate. Finally, we applied a multivariate analysis to explore the factors affecting litter size (total piglets born). Parity and lactation days had a direct and positive effect on litter size (Table $4, p<0.01$ ), while total piglets born was inversely related to pregnancy length. The LED photostimulation had no effect, the same as for boar, insemination person, or the interval of weaning-estrus (Table $4, p>0.05$ ). 
Table 2. Reproductive outcome of Iberian sows according to parity.

\begin{tabular}{|c|c|c|c|c|c|}
\hline Parity & $\mathbf{N}$ & Pregnancy Rate & Farrowing Rate & TB & NBA \\
\hline 2 & 403 & $90.82^{a b}$ & $87.34^{\mathrm{a}}$ & $7.93 \pm 0.11^{\mathrm{a}}$ & $7.77 \pm 0.11^{\mathrm{a}}$ \\
\hline 3 & 276 & $90.58^{a b}$ & $88.77^{a b}$ & $8.82 \pm 0.13^{b}$ & $8.64 \pm 0.13^{b}$ \\
\hline 4 & 188 & 89.89 ab & $88.30^{a b}$ & $8.86 \pm 0.16^{b}$ & $8.65 \pm 0.15^{b}$ \\
\hline 5 & 277 & $87.00^{a}$ & $85.56^{a}$ & $8.71 \pm 0.13^{b}$ & $8.47 \pm 0.13^{b}$ \\
\hline 6 & 637 & $93.25^{b}$ & $92.62^{b}$ & $8.85 \pm 0.08^{b}$ & $8.52 \pm 0.08^{b}$ \\
\hline 7 & 507 & $93.69^{b}$ & $91.52^{b}$ & $8.91 \pm 0.09^{b}$ & $8.54 \pm 0.09^{b}$ \\
\hline 8 & 512 & $92.97^{b}$ & $91.02^{b}$ & $8.8 \pm 0.09^{b}$ & $8.37 \pm 0.09^{b}$ \\
\hline$>8$ & 155 & $92.26^{\mathrm{ab}}$ & $90.32^{a b}$ & $8.66 \pm 0.17^{b}$ & $8.15 \pm 0.17^{b}$ \\
\hline \multicolumn{6}{|c|}{$p$ Value } \\
\hline \multicolumn{2}{|c|}{ Source of Variation } & Pregnancy Rate \% & Farrowing Rate \% & TB & NBA \\
\hline \multicolumn{2}{|c|}{ Treatment } & 0.40 & 0.76 & 0.98 & 0.75 \\
\hline \multicolumn{2}{|c|}{ Parity } & 0.03 & 0.02 & $<0.01$ & $<0.01$ \\
\hline \multicolumn{2}{|c|}{ Parity Treatment } & 0.03 & 0.47 & 0.80 & 0.99 \\
\hline
\end{tabular}

$\mathrm{a}, \mathrm{b}$ in the same column represent differences at $p<0.05$. TB: total number of piglets born. NBA: number of piglets born alive.

Table 3. Effect of boar and red LED light treatment on reproductive parameters. ANOVA source of variation.

\begin{tabular}{ccccc}
\hline Source of Variation & Pregnancy Rate \% & Farrowing Rate \% & TB & NBA \\
\hline Treatment & 0.61 & 0.73 & 0.18 & 0.16 \\
Boar & 0.10 & 0.02 & $<0.01$ & 0.02 \\
Boar Treatment & 0.39 & 0.53 & 0.50 & 0.54 \\
\hline
\end{tabular}

TB: total number of piglets born. NBA: number of piglets born alive.

Table 4. Multivariate analysis. Dependent variable: total piglets born $\mathrm{N}=2.567$ multiple $\mathrm{R} 0.12$ squared multiple R 0.01 .

\begin{tabular}{cccc}
\hline Effect & Coefficient & Standard Error & $p$-Value \\
\hline Parity & 0.07 & 0.02 & $<0.01$ \\
Interval weaning-oestrus (days) & 0.01 & 0.00 & 0.13 \\
Lactation length (days) & 0.04 & 0.01 & $<0.01$ \\
Pregancy length (days) & -0.08 & 0.03 & $<0.01$ \\
Boar & 0.00 & 0.00 & 0.30 \\
Insemination person & 0.00 & 0.00 & 0.07 \\
LED treatment & -0.12 & 0.07 & 0.09 \\
\hline
\end{tabular}

\section{Discussion}

In pigs, a red LED-based photostimulation procedure (10 min illumination, 10 darkness, and 10 illumination) is able to increase the whole boar sperm response to both the heat stress due to incubation at $37^{\circ} \mathrm{C}$ for $90 \mathrm{~min}$ and the achievement of in vitro capacitation and subsequent progesterone-induced acrosome reaction [4]. However, in later studies, other groups did not find any improvement in motility, mitochondrial activity, nor viability after the same illumination procedure [19]. Finally, an increase in motility parameters after red LED stimulation was detected, but no alteration in viability, ROS production, or intracellular calcium [20].

The presence of opsins in the spermatozoa, the modification of the mitochondrial activity, and activation of plasma membrane receptors from the transient receptor potential (TRP) family of proteins have been suggested as possible mechanisms of action of the illumination on the sperm functionality [21-25]. However, in this study, these reported changes in the sperm parameters had no effect on the subsequent reproductive outcomes, measured in terms of farrowing rate and litter size under commercial conditions. 
We hypothesize some different causes that could be related to these results. One hypothesis is that the possible improvement in the sperm parameters (not evaluated in this study) did not affect the reproductive outcomes because the insemination system was optimized (control group: $91.7 \%$ and $90.09 \%$ for pregnancy and farrowing rate). Under these circumstances, it is difficult to detect any improvement over these high values for reproductive parameters of the control group. Due to this, no relationship was found between sperm parameters and fertility as has previously been reported in other studies with more restrictive conditions [26-28]. On the other hand, the number of sperm in doses used in this study for post-cervical insemination was high $\left(3 \times 10^{9}\right.$ sperm per dose). According to the compensatory theory supported by Amman [29,30], an increase in the number of viable spermatozoa in seminal doses will show an asymptotic curve in their relationship to fertility, limited by the reproductive potential of the male. It could be possible that these Iberian sows were near their maximum potential for reproductive characteristics, determined by their genetic values, and any additional improvement in seminal parameters would have no significant effect on them. Therefore, if this hypothesis is true, the possible improvement in reproductive performance must be related to female improvement by genetic selection more than seminal parameters.

Another alternative could be that the response of Duroc samples to LED photostimulation is different than other breeds. Some studies have pointed out differences between Duroc boars and other breeds in seminal parameters (volume, concentration, motility, viability, etc.) [31-34], testosterone concentration [35], and proportion of discarded semen samples in AI centers [36]. Interestingly, Tremoen et al. [37] reported a higher proportion of hyperactivated spermatozoa in Duroc samples than landrace at day 0 of storage. These differences could indicate different susceptibilities to the capacitation kinetic, which could be explored in further studies.

\section{Conclusions}

In conclusion, the application of photostimulation with red LED on the seminal doses from Duroc boars used for insemination of Iberian sows did not improve the reproductive outcomes under commercial conditions. The litter size parameters of the Iberian sows might be improved by genetic selection or improvement of the female conditions more readily than by improvements in the artificial insemination system that has already been optimized.

Author Contributions: Conceptualization, S.C., J.G.; Data curation, S.C., M.M., J.G.; Formal analysis, J.G.; Investigation, S.C., M.M., J.G.; Methodology, S.C., M.M., J.G.; Supervision, J.G.; Writing—original draft, J.G.; Writing —review \& editing, S.C.; J.G. All authors have read and agreed to the published version of the manuscript.

Funding: Participation of J.G. in this work was supported by Fundación Séneca 20040/GERM/16 and 21105/PDC/19.

Institutional Review Board Statement: This project was authorized by the Ethical Committee at the University of Murcia and by the Animal Production Service of Agriculture Department of the Region of Murcia (Spain) (reference number A13170705).

Data Availability Statement: The data that support the findings of this study are available on request from the corresponding author.

Acknowledgments: We would like to acknowledge Bill Holt for the critical review of the manuscript.

Conflicts of Interest: The authors have read the journal's policy and have the following competing interests: the co-authors (S.C., M.M.) are employees of CEFU, S.A. that partially attended the project. The other authors have no competing interests. 


\section{References}

1. Zan-Bar, T.; Bartoov, B.; Segal, R.; Yehuda, R.; Lavi, R.; Lubart, R.; Avtalion, R.R. Influence of visible light and ultraviolet irradiation on motility and fertility of mammalian and fish sperm. Photomed. Laser Surg. 2005, 23, 549-555. [CrossRef]

2. Abdel-Salam, Z.; Harith, M.A. Laser researches on livestock semen and oocytes: A brief review. J. Adv. Res. 2015, 6, 311-317. [CrossRef]

3. Vladimirovich, M.S.; Ivanovich, A.O. Effectiveness of low level laser therapy for treating male infertility. Biomed. Taipei 2018, 8. [CrossRef]

4. Yeste, M.; Codony, F.; Estrada, E.; Lleonart, M.; Balasch, S.; Pena, A.; Bonet, S.; Rodriguez-Gil, J.E. Specific LED-based red light photo-stimulation procedures improve overall sperm function and reproductive performance of boar ejaculates. Sci. Rep. 2016, 6, 22569. [CrossRef]

5. Blanco Prieto, O.; Catalan, J.; Lleonart, M.; Bonet, S.; Yeste, M.; Rodriguez-Gil, J.E. Red-light stimulation of boar semen prior to artificial insemination improves field fertility in farms: A worldwide survey. Reprod. Domes. Anim. 2019, 54, 1145-1148. [CrossRef]

6. Gonzalez-Anover, P.; Encinas, T.; Torres-Rovira, L.; Pallares, P.; Munoz-Frutos, J.; Gomez-Izquierdo, E.; Sanchez-Sanchez, R.; Gonzalez-Bulnes, A. Ovulation rate, embryo mortality and intrauterine growth retardation in obese swine with gene polymorphisms for leptin and melanocortin receptors. Theriogenology 2011, 75, 34-41. [CrossRef] [PubMed]

7. Fernández, A.; Rodrigáñez, J.; Zuzúarregui, J.; Rodríguez, M.C.; Silió, L. Genetic parameters for litter size and weight at different parities in Iberian pigs. Span. J. Agric. Res. 2008, 6, 98. [CrossRef]

8. Noguera, J.L.; Ibanez-Escriche, N.; Casellas, J.; Rosas, J.P.; Varona, L. Genetic parameters and direct, maternal and heterosis effects on litter size in a diallel cross among three commercial varieties of Iberian pig. Animal 2019, 13, 2765-2772. [CrossRef] [PubMed]

9. Nieto, R.; García-Casco, J.; Lara, L.; Palma-Granados, P.; Izquierdo, M.; Hernandez, F.; Dieguez, E.; Duarte, J.; Batorek Lukač, N. Ibérico (Iberian) Pig. In European Local Pig Breeds-Diversity and Performance. A study of project TREASURE; Nieto, R., CandekPotokar, M., Eds.; IntechOpen: London, UK, 2019. [CrossRef]

10. Serrano, M.P.; Valencia, D.G.; Nieto, M.; Lázaro, R.; Mateos, G.G. Influence of sex and terminal sire line on performance and carcass and meat quality of Iberian pigs reared under intensive production systems. Meat Sci. 2008, 78, 420-428. [CrossRef]

11. Casellas, J.; Ibanez-Escriche, N.; Varona, L.; Rosas, J.P.; Noguera, J.L. Inbreeding depression load for litter size in Entrepelado and Retinto Iberian pig varieties1. J. Anim. Sci. 2019, 97, 1979-1986. [CrossRef]

12. Oliviero, C.; Junnikkala, S.; Peltoniemi, O. The challenge of large litters on the immune system of the sow and the piglets. Reprod. Domes. Anim. 2019, 54, 12-21. [CrossRef]

13. Silió, L. Iberian pig breeding programme. ICAR Tech. Ser. Italy 2000, 3, 511-519.

14. Perez-Patino, C.; Parrilla, I.; Barranco, I.; Vergara-Barberan, M.; Simo-Alfonso, E.F.; Herrero-Martinez, J.M.; Rodriguez-Martinez, H.; Martinez, E.A.; Roca, J. New In-depth analytical approach of the porcine seminal plasma proteome reveals potential fertility biomarkers. J. Proteome Res. 2018, 17, 1065-1076. [CrossRef] [PubMed]

15. King, G.J.; Macpherson, J.W. A comparison of two methods for boar semen collection. J. Anim. Sci. 1973, 36, 563-565. [CrossRef] [PubMed]

16. Navarro-Serna, S.; París-Oller, E.; Simonik, O.; Romar, R.; Gadea, J. Replacement of Albumin by Preovulatory Oviductal Fluid in Swim-Up Sperm Preparation Method Modifies Boar Sperm Parameters and Improves In Vitro Penetration of Oocytes. Animals 2021, 11, 1202. [CrossRef] [PubMed]

17. Hernandez-Caravaca, I.; Izquierdo-Rico, M.J.; Matas, C.; Carvajal, J.A.; Vieira, L.; Abril, D.; Soriano-Ubeda, C.; Garcia-Vazquez, F.A. Reproductive performance and backflow study in cervical and post-cervical artificial insemination in sows. Anim. Reprod. Sci. 2012, 136, 14-22. [CrossRef] [PubMed]

18. Dupont, W.D.; Plummer, W.D., Jr. Power and sample size calculations for studies involving linear regression. Control. Clin. Trials 1998, 19, 589-601. [CrossRef]

19. Luther, A.; Le Thi, X.; Schafer, J.; Schulze, M.; Waberski, D. Irradiation of semen doses with LED-based red light in a photo chamber does not improve in vitro quality of thermically stressed boar spermatozoa. Reprod. Domes. Anim. 2018, 53, 1016-1019. [CrossRef] [PubMed]

20. Pezo, F.; Zambrano, F.; Uribe, P.; Ramirez-Reveco, A.; Romero, F.; Sanchez, R. LED-based red light photostimulation improves short-term response of cooled boar semen exposed to thermal stress at 37 degrees C. Andrologia 2019, 51, e13237. [CrossRef]

21. Yeste, M.; Castillo-Martin, M.; Bonet, S.; Rodriguez-Gil, J.E. Impact of light irradiation on preservation and function of mammalian spermatozoa. Anim. Reprod. Sci. 2018, 194, 19-32. [CrossRef]

22. Rodriguez-Gil, J.E. Photostimulation and thermotaxis of sperm: Overview and practical implications in porcine reproduction. Theriogenology 2019, 137, 8-14. [CrossRef] [PubMed]

23. Blanco-Prieto, O.; Catalan, J.; Trujillo-Rojas, L.; Pena, A.; Rivera Del Alamo, M.M.; Llavanera, M.; Bonet, S.; Fernandez-Novell, J.M.; Yeste, M.; Rodriguez-Gil, J.E. Red LED Light Acts on the Mitochondrial Electron Chain of Mammalian Sperm via Light-Time Exposure-Dependent Mechanisms. Cells 2020, 9, 2546. [CrossRef] [PubMed]

24. Lone, S.A.; Mohanty, T.K.; Kumaresan, A.; Bhakat, M. Laser irradiation effects and its possible mechanisms of action on spermatozoa functions in domestic animals. Asian Pac. J. Reprod. 2017, 6, 97-103. [CrossRef]

25. Zupin, L.; Pascolo, L.; Luppi, S.; Ottaviani, G.; Crovella, S.; Ricci, G. Photobiomodulation therapy for male infertility. Lasers Med. Sci. 2020, 35, 1671-1680. [CrossRef] 
26. Gadea, J.; Selles, E.; Marco, M.A. The predictive value of porcine seminal parameters on fertility outcome under commercial conditions. Reprod. Domes. Anim. 2004, 39, 303-308. [CrossRef] [PubMed]

27. Broekhuijse, M.L.; Sostaric, E.; Feitsma, H.; Gadella, B.M. The value of microscopic semen motility assessment at collection for a commercial artificial insemination center, a retrospective study on factors explaining variation in pig fertility. Theriogenology 2012, 77, 1466-1479.e1463. [CrossRef]

28. Broekhuijse, M.L.; Feitsma, H.; Gadella, B.M. Field data analysis of boar semen quality. Reprod. Domes. Anim. 2011, 46, 59-63. [CrossRef]

29. Amann, R.P.; Hammerstedt, R.H. Detection of differences in fertility. J. Androl. 2002, 23, 317-325.

30. Amann, R.P.; Saacke, R.G.; Barbato, G.F.; Waberski, D. Measuring Male-to-Male Differences in Fertility or Effects of Semen Treatments. Annu. Rev. Anim. Biosci. 2018, 6, 255-286. [CrossRef]

31. Borg, K.E.; Lunstra, D.D.; Christenson, R.K. Semen characteristics, testicular size, and reproductive hormone concentrations in mature duroc, meishan, fengjing, and minzhu boars. Biol. Reprod. 1993, 49, 515-521. [CrossRef]

32. Kennedy, B.; Wilkins, J. Boar, breed and environmental factors influencing semen characteristics of boars used in artificial insemination. Can. J. Anim. Sci. 1984, 64, 833-843. [CrossRef]

33. Kondracki, S. Breed differences in semen characteristics of boars used in artificial insemination in Poland. Pig News Inf. 2003, 24, 119-122.

34. Martin-Hidalgo, D.; Baron, F.J.; Robina, A.; Bragado, M.J.; Llera, A.H.; Garcia-Marin, L.J.; Gil, M.C. Inter- and intra-breed comparative study of sperm motility and viability in Iberian and Duroc boar semen during long-term storage in MR-A and XCell extenders. Anim. Reprod. Sci. 2013, 139, 109-114. [CrossRef]

35. Park, C.S.; Yi, Y.J. Comparison of semen characteristics, sperm freezability and testosterone concentration between Duroc and Yorkshire boars during seasons. Anim. Reprod. Sci. 2002, 73, 53-61. [CrossRef]

36. Wang, C.; Guo, L.L.; Wei, H.K.; Zhou, Y.F.; Tan, J.J.; Sun, H.Q.; Jiang, S.W.; Peng, J. Logistic regression analysis of the related factors in discarded semen of boars in Southern China. Theriogenology 2019, 131, 47-51. [CrossRef] [PubMed]

37. Tremoen, N.H.; Gaustad, A.H.; Andersen-Ranberg, I.; van Son, M.; Zeremichael, T.T.; Frydenlund, K.; Grindflek, E.; Vage, D.I.; Myromslien, F.D. Relationship between sperm motility characteristics and ATP concentrations, and association with fertility in two different pig breeds. Anim. Reprod. Sci. 2018, 193, 226-234. [CrossRef] [PubMed] 